\title{
PERUBAHAN TUTUPAN LAHAN HUTAN LINDUNG GUNUNG GUNTUR TAHUN 2014 SAMPAI DENGAN TAHUN 2017
}

The Change of Cover Land Use in Mt. Guntur Protected Forest on 2014 to 2017

\section{Prasetyo Widodo; Abdul Japar Sidik}

Universitas Winaya Mukti, Jl. Raya Sumedang Km 29 Tanjungsari-Sumedang 45362; fahutan@unwim.ac.id

\section{Diterima 10 Februari 2018/Disetujui 25 Februari 2018}

\begin{abstract}
High pressure by community activities on the existence of forests, especially protected forests that affect the quality of the environment that can cause a disaster, such as the occurrence of flash floods that occurred in 2016 in Garut regency, cannot be separated from damage to the upstream cover of cimanukcitanduy. This prompted investigators to analyze the three year change of land protection prevailing in Mt. Guntur RPH Simpang BKPH Bayongbong. The objective of research is to calculate how large changes land cover area in Mt. Guntur Protected Area (MGPA), RPH Simpang BKPH Bayongbong KPH Garut in three years. The data collected on July to August 2017 by geographic information system (GIS) and satellite image. The results of land cover interpretation by landsat 8 OLI image 2014 and 2017 describe the condition of land use and land cover change in MGPA. Land cover of MGPA dominated by shrub (B) is 287.58 Ha (57.52\%) at 2014 and $202.89 \mathrm{Ha} \mathrm{(40.58 \% )} \mathrm{at} \mathrm{2017,} \mathrm{so}$ deforestation as three years is $31.24 \mathrm{Ha}$ or $32.13 \%$. The results of ground check there is a land use change to open land and farming dryland. According to data of image interpretation at 2017, the open land is 20.03 Ha but after ground checking is $20.51 \mathrm{Ha}$. The reduction of it based on data of image interpretation at 2017 is 200.33 Ha to 201.85 Ha after ground checking.
\end{abstract}

Keywords: Cover land use, Mt. Guntur protected area, GIS

\section{PENDAHULUAN}

\section{Latar Belakang}

Hutan sebagai salah satu sumber daya alam hayati mempunyai peranan penting bagi kehidupan manusia, baik dari segi ekonomi, sosial, budaya dan segi yang lainnya. Berdasarkan Undang-Undang Kehutanan 41 Tahun 1999 Fungsi 
Hutan di Indonesia dibagi menjadi Fungsi Produksi, Konservasi dan Lindung. Hutan Lindung didefinisikan sebagai kawasan hutan yang mempunyai fungsi pokok sebagai perlindungan sistem penyangga kehidupan untuk mengatur tata air, mencegah banjir, mengendalikan erosi, mencegah intrusi air laut dan memelihara kesuburan tanah. Oleh karena itu pengelolaan dan pemanfaatan hutan harus dilakukan secara benar dan rasional agar diperoleh manfaat yang optimal serta lestari.

Hutan lindung di Jawa Barat berdasarkan SK Menhut No. 195/Kpts-II/2003 tentang Penunjukan Kawasan Hutan di Wilayah Provinsi Jawa Barat adalah 291.300 Ha. Luas hutan lindung tersebut diantaranya tersebar di Kabupaten garut seluas 75.572,00 Ha (70,06\%). Berdasarkan Buku Potret Keadaan Hutan Indonesia periode 2009-2013, bahwa luas deforestasi di Provinsi Jawa Barat termasuk di Kabupaten garut dalam kurun waktu 2009-2013 adalah seluas 111.111 Ha atau setara dengan 27.778 Ha per tahun (FWI, 2014).

Tingginya tekanan oleh aktivitas masyarakat terhadap keberadaan hutan khususnya hutan lindung yang berdampak menurunnya kualitas lingkungan yang dapat menyebabkan terjadinya bencana, seperti halnya telah terjadinya bencana banjir bandang yang terjadi pada tahun 2016 di Kabupaten Garut, tidak lepas dari rusaknya tutupan lahan dikawasan hulu sungai cimanuk-citanduy. Hal ini mendorong peneliti untuk menganalisis perubahan tutupan lahan selama kurun waktu tiga tahun yang terjadi di Hutan Lindung Gn. Guntur RPH Simpang BKPH Bayongbong. Luasan hutan lindung Gunung Guntur adalah 1.358 Ha, sedangkan data yang digunakan untuk areal penelitian adalah seluas $500 \mathrm{Ha}$ (mewakili seluruh tutupan hutan lindung). Perkembangan perubahan tutupan lahan yang terjadi dapat diketahui dengan menggunakan teknologi penginderaan jauh dan sistem informasi geografis (SIG). Hal ini dikarenakan penginderaan jauh memiliki kemampuan dapat memberikan informasi secara lengkap, cepat dan relatif akurat, serta dapat mempermudah pekerjaan lapangan dan biaya yang relatif murah. Laju perubahan hutan dapat dihitung berdasarkan perbandingan gambar satelit (citra digital) atas liputan lahan pada dua tahun atau lebih yang berbeda, serta dengan melakukan penciptaan gambar (tekstur, warna, dan ketajaman) yang sama (Sunderlin 2012).

Faktor penyebab kerusakan hutan menurut Silviani (2008) adalah faktor ekonomi masyarakat di sekitar hutan yang digambarkan sebagai masyarakat petani miskin dan aspek pengamanan hutan yaitu terbatasnya jumlah petugas pengawas kehutanan mendorong berkembangnya free rider dan pelaku ekonomi melakukan praktik illegal logging sehingga menyebabkan masuknya perambah hutan (Rachman Effendi at al, 2007) sehingga adanya perubahan penutupan lahan secara cepat dan dinamis. Dalam hal ini menunjukan potensi kerusakan hutan di 
Jawa Barat pada saat ini dan masa mendatang cukup tinggi. Tujuan yang ingin dicapai dalam pelaksanaan penelitian ini adalah untuk mengetahui perubahan tutupan lahan yang terjadi dikawasan Hutan Lindung Gn. Guntur BKPH Bayongbong RPH Simpang pada kurun waktu tiga tahun.

\section{METODE PENELITIAN}

Kegiatan penelitian dilakukan pada kawasan Hutan Lindung Gn. Guntur RPH Simpang, BKPH Bayongbong, KPH Garut. Sesuai dengan Surat Keputusan Direksi Perum Perhutani Nomor : 908/KPTS/DIR/2013 Tentang Pembagian Kawasan Hutan Pada Kesatuan Pemangkuan Hutan Garut dengan luas $1.358 \mathrm{Ha}$ dan data yang diambil seluas $500 \mathrm{Ha}$, koordinat $107^{\circ} 44^{\prime} 00^{\prime}$ ' Bujur Timur 07 $14^{\prime} 00^{\prime}$ ' Lintang Selatan, ketinggian 1.400-1.800 Mdpl dan jenis tanah latosol (Gambar 1).

Peralatan yang digunakan dalam pengambilan dan pengukuran data dilapangan yaitu alat tulis, teropong binoculer, kamera, kompas peta kawasan dan Global Positioning System (GPS) dan alat ukur lapangan lainnya.Untuk pengolahan dan analisis data, yaitu Software Arc.GIS 10.3, Software Microscoft office, Peta Rupa Bumi Indonesia, Peta Batas Hutan Lindung RPH Simpang kawasan Gn.Guntur, data kependudukan (demografi) dan data sosial ekonomi yang berasal dari instansi terkait seperti kantor Biro Pusat Statistik (BPS).

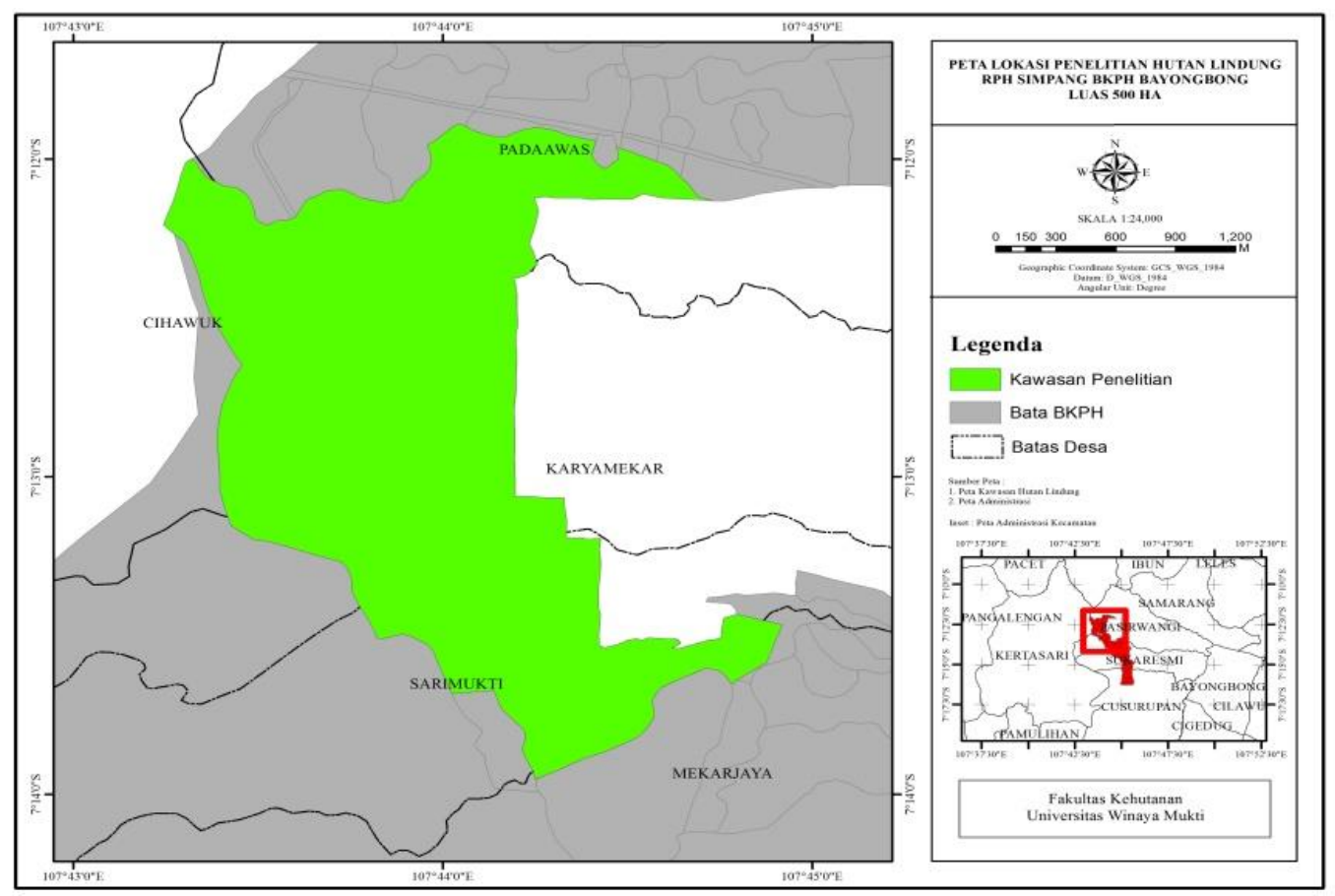

Gambar 1. Peta Lokasi Penelitian 
Pembuatan peta digital lokasi penelitian dalam sistem informasi geografis dipermenstasikan dalam dua format yaitu vektor dan raster. Data spasial format vektor pada penelitian ini adalah berupa peta hasil Rekontruksi Batas Kawasan Hutan Lindung Gn. Guntur Kabupaten Garut yang selanjutnya dikonversi menjadi peta digital melalui proses screen digitzing dengan menggunakan seperangkat laptop dengan software Arc.GIS 10,3. Peta hasil digitasi kemudian digunakan sebagai acuan wilayah penelitian serta acuan untuk koreksi geometrik pada saat pengolahan citra landast. Data spasial lainnya adalah peta digital RBI, data GPS berupa titik GCP (Ground control Point) dan titik ikat dilapangan, data ini merupakan data yang menyatakan posisi objek dipermukaan bumi dalam bentuk titik yang diketahui koordinatnya. Proses konversi peta dasar ke peta digital dapat dilihat pada Gambar 2.

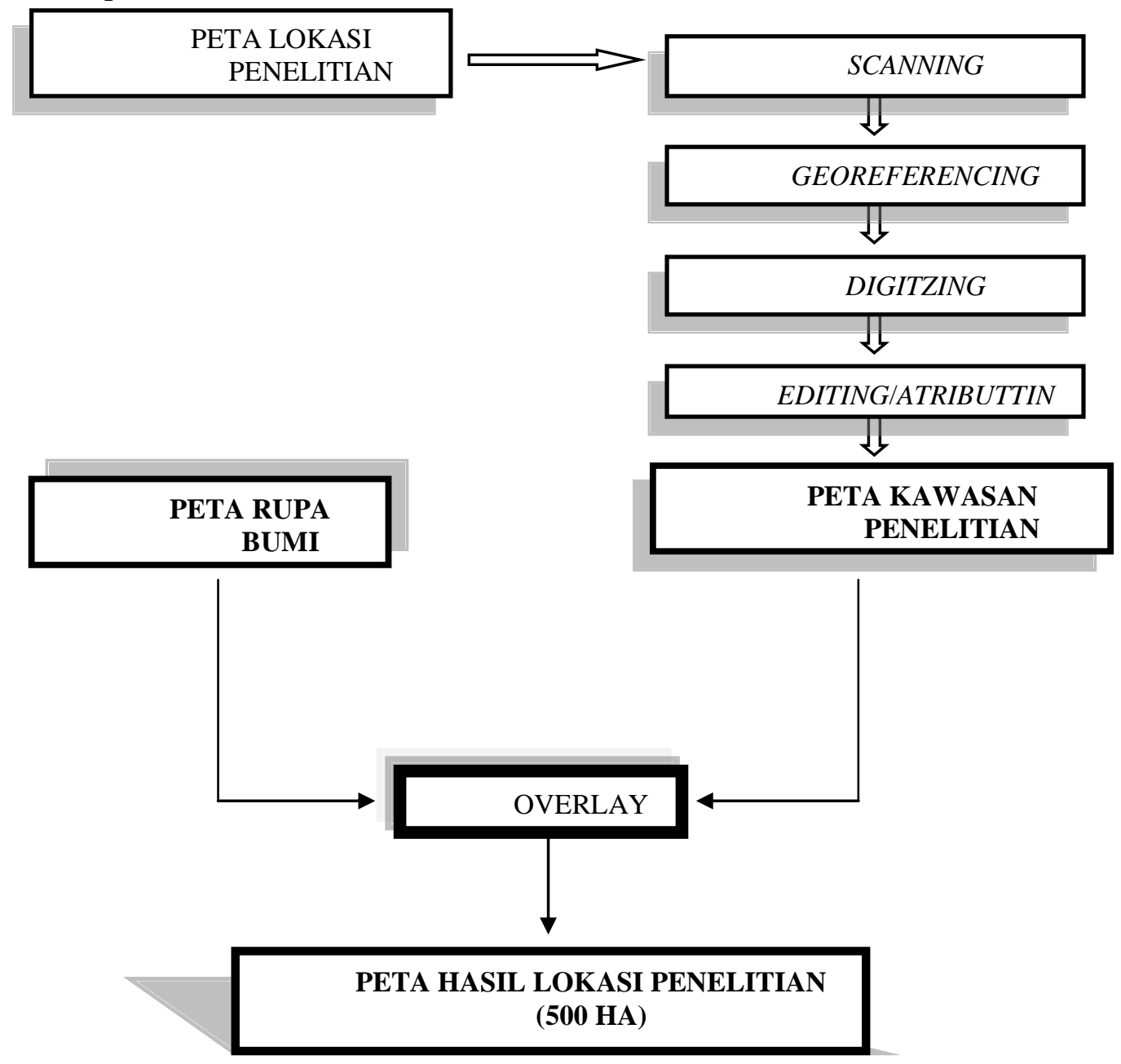

Gambar 2. Proses konversi peta dasar ke peta digital

Penelitian dilakukan melalui beberapa proses kegiatan diantaranya tahapan persiapan, tahapan pengeolahan data, tahap analisis dan tahap akhir. Tahap persiapan diawali dengan identifikasi masalah. Tahap awal yakni penentuan 
masalah yang berhubungan dengan rencana pekerjaan dan penetapan tujuan. selanjutnya studi literatur yaitu mempelajari dan mengumpulkan buku-buku referensi dan hasil penelitian sejenis sebelumnya yang pernah dilakukan oleh orang lain yang berkaitan. Tujuannya ialah untuk mendapatkan landasan teori mengenai masalah yang akan diteliti. Tahap persiapan diakhiri dengan pengumpulan data. Analisis interpretasi citra diolah menggunakan Sistem Informasi Geografis (SIG) (Baja, 2012).

Tahapan yang dilakukan dalam pengolahan data spasial adalah sebagai berikut :

1. Perubahan Format

Citra satelit landsat 8 (OLI) yang telah di unduh memiliki format data dalam bentuk GeoTiff/ .TIFF, sehingga perlu dilakukan perubahan format ke dalam bentuk Image/ .img.

2. Perbaikan Citra (Image Restoration)

Perbaikan Citra dilakukan terhadap data citra satelit, yang dimaksudkan untuk menghilangkan kesalahan-kesalahan radiometrik dan geometrik yang terdapat pada data citra satelit tersebut. Hal pertama yang perlu dilakukan dalam koreksi geometrik adalah penentuan tipe proyeksi dan sisitem koordinat yang digunakan untuk mempermudah dalam proses pengintregasian data-data selama penelitian. Perbaikan distorsi geometrik dapat dilakuakan dengan mengambil titik-titik ikat dilapangan yang bersifat permanen.

3. Pemotongan Citra (Subset Image)

Pemotongan citra dilakukan dengan memotong wilayah yang menjadi obyek penelitian, dimana Peta Hasil Rekontruksi Batas Kawasan Hutan Lindung RPH Simpang Gn. Guntur Kabupaten Garut hasil digitasi (peta digital) dapat disajikan acuan pemotongan citra.

4. Klasifikasi Citra (Image Classification)

Persiapan yang harus dilakukan sebelum melakuakan pengklasifikasian adalah menetapkan kelas-kelas spektral yang terliput oleh citra satelit, Pembagian kelas klasifikasi dibatasi menurut kebutuhan pengklasifikasian.

Teknik pengklasifikasian penutupan lahan yang digunakan adalah dengan cara interpretasi visual meliputi tahapan sebagai berikut :

a. Pengenalan pola-pola sprektral yang ditampilkan oleh citra yang telah terkoreksi melalui Georeferencing.

b. Pemilihan daerah (area of intersest) yang di identifikasikan sebagai satu tipe penutupan lahan berdasarkan pola-pola spektral yang ditampilkan oleh citra landsat.

c. Proses interpretasi citra secara visual berdasarkan pola-pola spektral yang telah ditetapkan pada saat proses pemilihan daerah. 
d. Pengecekan lapangan pada daerah terpilih yang mewakili seluruh kelas penutupan lahan yang telah ditentukan.

Alur pengolahan citra satelit dalam interpretasi perubahan tutupan lahan bedasarkan citra tahun 2014 dan 2017 adalah sebagai berikut :

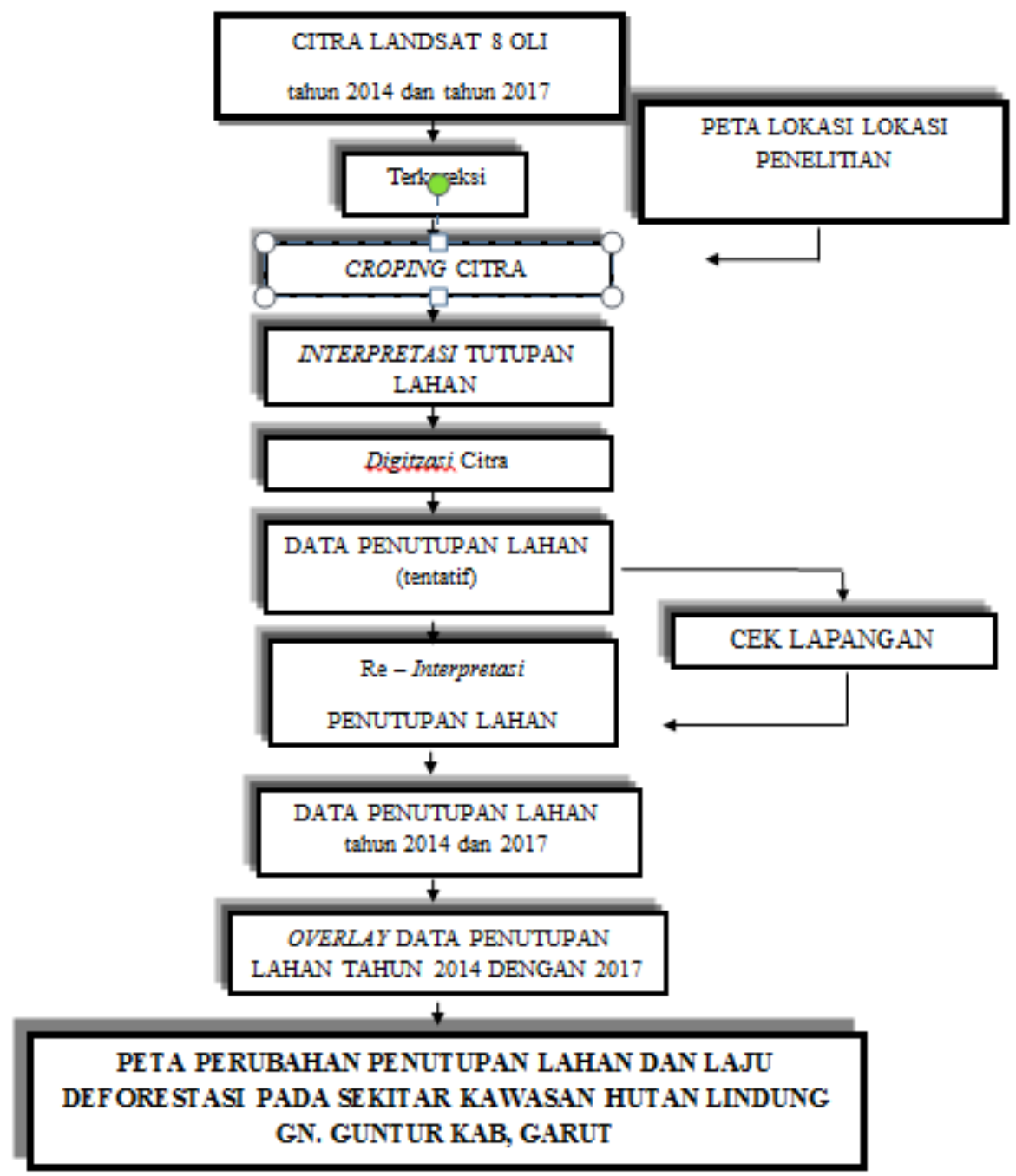

Gambar 3. Bagan Interpretasi tutupan lahan

Uji ketelitian interpretasi yang dilakuakan meliputi empat tahap sebagai berikut :

1. Melakukan pengecekan lapangan yang telah dipilih dari setiap bentuk penutupan atau penggunaan lahan. Uji ketelitian dilakukan pada setiap area sampel penutupan atau penggunaan lahan yang homogen.

2. Membuat tabel hasil pengecekan lapangan pada setiap bentuk penutupan atau penggunaan lahan yang telah dipilih dan membandingkan dengan hasil interpretasi. 
3. Menilai kecocokan hasil interprestasi setiap citra dengan peta referensi atau citra landsat pada daerah yang sama dengan waktu yang sama.

\section{HASIL DAN PEMBAHASAN}

\section{Interpretasi Tutupan Lahan}

Penginterpretasian pada citra yang telah terkoreksi geometri dilakukan dengan mempelajari dan mengamati sifat-sifat kenampakan pada citra dalam hal ini disebut klasifikasi. Klasifikasi penutupan lahan dan penggunaan lahan adalah upaya pengelompokan berbagai jenis penutup lahan/penggunaan lahan ke dalam suatu kesamaan sesuai dengan sistem tertentu. Hasil interpretasi tutupan lahan menggunakan citra Landsat 8 OLI tahun 2014 dan 2017 untuk menggambarkan keadaan perubahan tutupan dan penggunaan lahan di wilayah hutan lindung RPH Simpang BKPH Bayongbong Gn. Guntur. Klasifikasi penutup lahan atau penggunaan lahan dalam proses interpretasi citra penginderaan jauh juga dapat digunakan sebagai pedoman atau acuan dalam penggunaan lahan. Banyak sistem klasifikasi penutup/penggunaan lahan yang telah dikembangkan, yang dilatarbelakangi oleh kepentingan tertentu (Jaya, 2010).

Hutan lindung RPH Simpang BKPH Bayongbong Gn Guntur adalah salah satu kawasan hutan lindung yang berada di Kabupaten Garut yang memliki beberapa tipe tutupan lahan. Untuk mengetahui tutupan lahan tersebut diperlukan suatu teknik yang digunakan dalam mengidentifikasi tipe tutupan lahan. Pada penelitian ini teknik yang digunakan adalah teknik penginderaan jauh dengan menggunakan citra landsat 8 OLI tahun liputan tahun 2014 dan tahun 2017.

Tipe tutupan lahan di hutan lindung RPH Simpang BKPH Bayongbong didominasi oleh semak belukar (B) seluas $287.58 \mathrm{Ha}(57.52 \%)$ pada tahun 2014 dan $202.89 \mathrm{Ha}(40.58 \%)$ pada tahun 2017, sedangkan laju deforestasi dalam kurun waktu tiga tahun $31.24 \mathrm{Ha}$ atau $32.13 \%$. Kondisi tutupan lahan yang seperti ini memberikan indikasi bahwa kondisi tutupan lahan hutan lindung RPH Simpang BKPH Bayongbong mengalami penurunan fungsi yang besar, maka kemungkinan akan mengakibatkan degradasi lingkungan yang lebih buruk dan merugikan.

Menurut Adnyana (2011) penggunaan lahan dikelompokkan menjadi tujuh kategori, yaitu hutan, semak/belukar, kebun campuran, pemukiman, sawah, tegalan, dan lahan terbuka, sedangkan secara umum pada lokasi penelitian diklasifikasikan kedalam enam tipe tutupan lahan yaitu : 1. Hutan sekunder, (2) semak belukar (3) pertanian lahan kering (4) lahan terbuka (5) lahan terbangun (6) awan. Penafsiran citra dilakukan secara visual pada layar komputer (on screen 
digitizing) dengan skala digitasi yang digunakan adalah 1:2.000. Hasil akhir penafsiran tutupan lahan diuji akurasinya dengan melakukan pengecekan lapangan.

Hasil interpretasi citra tahun 2014 dan 2017 di kawasan hutan lindung RPH simpang BKPH Bayongbong mengalami perubahan tutupan lahan. Tutupan lahan diklasifikasikan menjadi 2, yaitu citra tutupan lahan tahun 2014 dan citra tutupan lahan tahun 2017. Citra tutupan lahan tahun 2014 terdiri dari (Tabel 1) : Hutan Sekunder (Hs), Semak Belukar (B), Pertanian Lahan Kering (Pt), Lahan Terbuka (T), Lahan Terbangun (Pm) dan Awan (Aw), sedangkatan citra tutupsn lahan tahun 2017 terdiri dari (Tabel 2) : Hutan Sekunder (Hs), Semak Belukar (B), Pertanian Lahan Kering (Pt), Lahan Terbuka (T) dan Lahan Terbangun (Pm).

Tabel.1. Tutupan Lahan Kawasan Hutan Lindung RPH simpang BKPH Bayongbong pada tahun 2014

\begin{tabular}{clcc}
\hline \multirow{2}{*}{ No } & \multirow{2}{*}{ Keterangan } & \multicolumn{2}{c}{ Tahun 2014 } \\
\cline { 3 - 4 } & & Luas (Ha) & Persentase (\%) \\
\hline 1 & Hutan Sekunder & 97.24 & 19.45 \\
2 & Semak Belukar & 287.58 & 57.52 \\
3 & Pertanian Lahan Kering & 2,60 & 0,52 \\
4 & Lahan Terbuka & 97,51 & 19,50 \\
5 & Lahan Terbangun & 6,39 & 1,28 \\
6 & Awan & 8,68 & 1,74 \\
& Jumlah & 500 & 100 \\
\hline
\end{tabular}

Tabel 2. Tutupan Lahan Kawasan Hutan Lindung RPH simpang BKPH Bayongbong pada tahun 2017

\begin{tabular}{llcc}
\hline \multirow{2}{*}{ No } & Keterangan & \multicolumn{2}{c}{ Tahun 2017 } \\
\cline { 3 - 4 } & & Luas (Ha) & Persentase (\%) \\
\hline 1 & Hutan Sekunder & 66.00 & 13.20 \\
2 & Semak Belukar & 202.89 & 40.58 \\
3 & Pertanian Lahan Kering & 200.33 & 40.18 \\
4 & Lahan Terbuka & 22.03 & 4.41 \\
5 & Lahan Terbangun & 8.76 & 1,75 \\
& Jumlah & 500 & 100 \\
\hline
\end{tabular}

Klasifikasi tutupan lahan kawasan hutan lindung RPH Simpang BKPH Bayongbong berdasarkan Tabel 1 dan Tabel 2 sebagai berikut :

\section{Hutan Sekunder}

Kawasan hutan sekunder di kawasan hutan lindung RPH Simpang BKPH Bayongbong telah terjadi perubahan tutupan lahan dimana terjadi penurunan luasan dari tahun 2014 seluas $97.24 \mathrm{Ha}$ (19.45\% dari total luas lokasi penelitian) 
menjadi tinggal $66.00 \mathrm{Ha}(13.20 \%)$ pada tahun 2017. Laju pengurangan kawasan hutan sekunder dari tahun 2014 sampai tahun 2017 sebesar $31.24 \mathrm{Ha}$ atau sebesar 10.4 Ha/tahun. Dimana jenis tutupan lahannya berubah menjadi semak belukar seluas 27.13 Ha dan menjadi pertanian lahan kering seluas 4.11 Ha.

Perubahan lahan dari kawasan hutan sekunder menjadi kawasan semak belukar dan pertanian lahan kering ini jika tidak dikendalikan dikhawatirkan akan membawa dampak negatif, diantaranya adalah semakin besarnya laju erosi dan sedimentasi sungai yang dapat mengakibatkan banjir bila terjadi hujan terusmenerus, karena semakin berkurangnya kawasan hutan sekunder berarti semakin berkurangnya kawasan resapan air dan selain itu kawasan tersebut terletak pada daerah hulu DAS Cimanuk.

\section{Semak Belukar}

Kawasan semak belukar di kawasan hutan lindung RPH Simpang BKPH Bayongbong terjadi fluktuasi perubahan luasannya pada tahun 2014 seluas 287.58 Ha (57.52\% dari total luas lokasi penelitian) menjadi tinggal $202.89 \mathrm{Ha} \mathrm{(40.58}$ \%) pada tahun 2017. Laju pengurangan kawasan semak belukar dari tahun 2014 sampai tahun 2017 sebesar $84.68 \mathrm{Ha}$ atau sebesar 28.2 Ha/tahun. Dimana jenis penggunaan lahannya berubah menjadi menjadi pertanian lahan kering seluas 84.68 Ha. Fluktuasi perubahan luasan ini banyak dijadikan lahan terbuka yang nantinya dijadikan perluasan pertanian lahan kering oleh masyarakat sekitar.

\section{Pertanian Lahan Kering}

Kawasan pertanian lahan kering terjadi perubahan fluktuasi yang sangat besar dari tipe tutupan lahan lainnya dimana terjadi peningkatan luasan, pada tahun 2014 seluas $2.60 \mathrm{Ha}(0.52 \%$ dari total luas lokasi penelitian) menjadi seluas $200.33 \mathrm{Ha}(40.18 \%$ ) pada tahun 2017. Laju penambahan luasan pertanian lahan kering dari tahun 2014 sampai tahun 2017 sebesar 197.73 Ha atau rata-rata sebesar $65.91 \mathrm{Ha} /$ tahun. Luasan pertanian lahan kering bertambah dikarenakan adanya kegiatan konversi lahan terbuka dan perladangan oleh masyarakat. Dimana masyarakat desa pada umumnya hanya mengandalkan sumber mata pencariannya dari sektor pertanian. Keterbatasan lahan yang dimiliki oleh setiap keluarga serta peningkatan kebutuhan menyebabkan sebagian masyarakat yang kurang mampu melakukan penggarapan lahan dan konversi lahan untuk perluasan areal pertaniannya, hal ini akan terus berlangsung melihat peningkatan tutupan lahan pada pertanian lahan kering dan akan mengakibatkan perubahan penutupan lahan dari berbagai tipe tutupan lahan lainnya. 


\section{Lahan Terbuka}

Kawasan lahan terbuka telah terjadi penurunan luasan dari dari tahun 2014 seluas $97.51 \mathrm{Ha}(19,50 \%$ dari total luas lokasi penelitian) menjadi $22.03 \mathrm{Ha}$ (4.41\%) pada tahun 2017. Laju pengurangan kawasan lahan terbuka dari tahun 2014 sampai tahun 2017 sebesar $75.48 \mathrm{Ha}$ atau sebesar $25.16 \mathrm{Ha} /$ tahun. Pengurangan luasan ini karenakan terjadinya konversi menjadi bangunan sebesar $2.37 \mathrm{Ha}$ dan pertanian lahan kering seluas $73.11 \mathrm{Ha}$. Kawasan lahan terbuka biasanya adalah kawasan persiapan untuk dijadikan pertanian lahan kering oleh masyarakat bahkan dijadikan kawasan pembangunan Pembangkit Listrik Tenaga Panas Bumi (PLTP) dikelola oleh Amoseas Indonesia.Inc anak perusahaan Chevron Texaco. Jika kawasan lahan terbuka dibiarkan dan bertambahannya semakin besar dikhawatirkan daerah resapan air untuk wilayah hulu DAS Cimanuk akan semakin sedikit dan berakibat buruk bagi sistem hirdrologi.

\section{Lahan Terbangun}

Kawasan lahan terbangun terjadi kenaikan luasan dari tahun 2014 seluas $6.39 \mathrm{Ha}$ (1.28\% dari total luas lokasi penelitian) menjadi seluas $8.76 \mathrm{Ha}(1.75 \%)$ pada tahun 2017. Perubahan kawasan lahan terbuka dari tahun 2014 sampai tahun 2017 sebesar 2.37 Ha. Laju pertambahan kawasan lahan terbangun dikarenakan kawasan ini memiliki sumber daya panas bumi sehingga dijadikan Kawasan Pembangkit Listrik Tenaga Panas Bumi (PLTP) dikelola oleh Amoseas Indonesia.Inc anak perusahaan Chevron Texaco, dimana adanya bangunanbangunan dan pipa-pipa untuk kegiatan aktivitas PLTP. Adanya bangunan dikawasan Huatan Lindung ini berdasarkan Peraturan Pemerintah Republik Indonesia Nomor 61 Tahun 2012 Tentang perubahan Atas Peraturan Pemerintah Nomor 24 Tahun 2010 Tentang Penggunaan Kawasan Hutan, dimana dalam Peraturan Pemerintah dijelaskan pada ayat (2) Pasal 4 diubah, sehingga Pasal 4 berbunyi sebagai berikut : Pasal 4 (1) Penggunaan kawasan hutan untuk kepentingan pembangunan di luar kegiatan hanya dapat dilakukan untuk kegiatan yang mempunyai tujuan strategis yang tidak dapat dielakkan, diantaranya intalasi pembangkit listrik panas bumi.

\section{Awan}

Hasil interpretasi citra pada citra tahun 2014 terdapat awan yang menutupi dimana awan pada setiap citra selalu ada disaat waktu pemotretan, di citra tahun 2014 terdapat seluas $8.68 \mathrm{Ha}$ atau $1.74 \%$ dari luas lokasi penelitian, sedangkan pada citra tahun 2017 tidak terdapat tutupan awan.

Tutupan lahan hasil interpretasi citra pada tahun 2014 dan 2017 telah mengalami perubahan dan pengurangan luasan antara lain (Gambar 1) : 1) hutan 
sekunder mengalami pengurangan luasan dan berubah fungsi, yaitu dari luas 97,24 Ha (tahun 2014) menjadi $66 \mathrm{Ha}$ (tahun 2017) dan berubah fungsi menjadi semak belukar $(27,13 \mathrm{Ha})$ dan pertanian lahan kering (4,11 Ha); 2) Semak belukar menjadi pertanian lahan kering; 3) Lahan terbuka menjadi bangunan dan pertanian lahan kering.

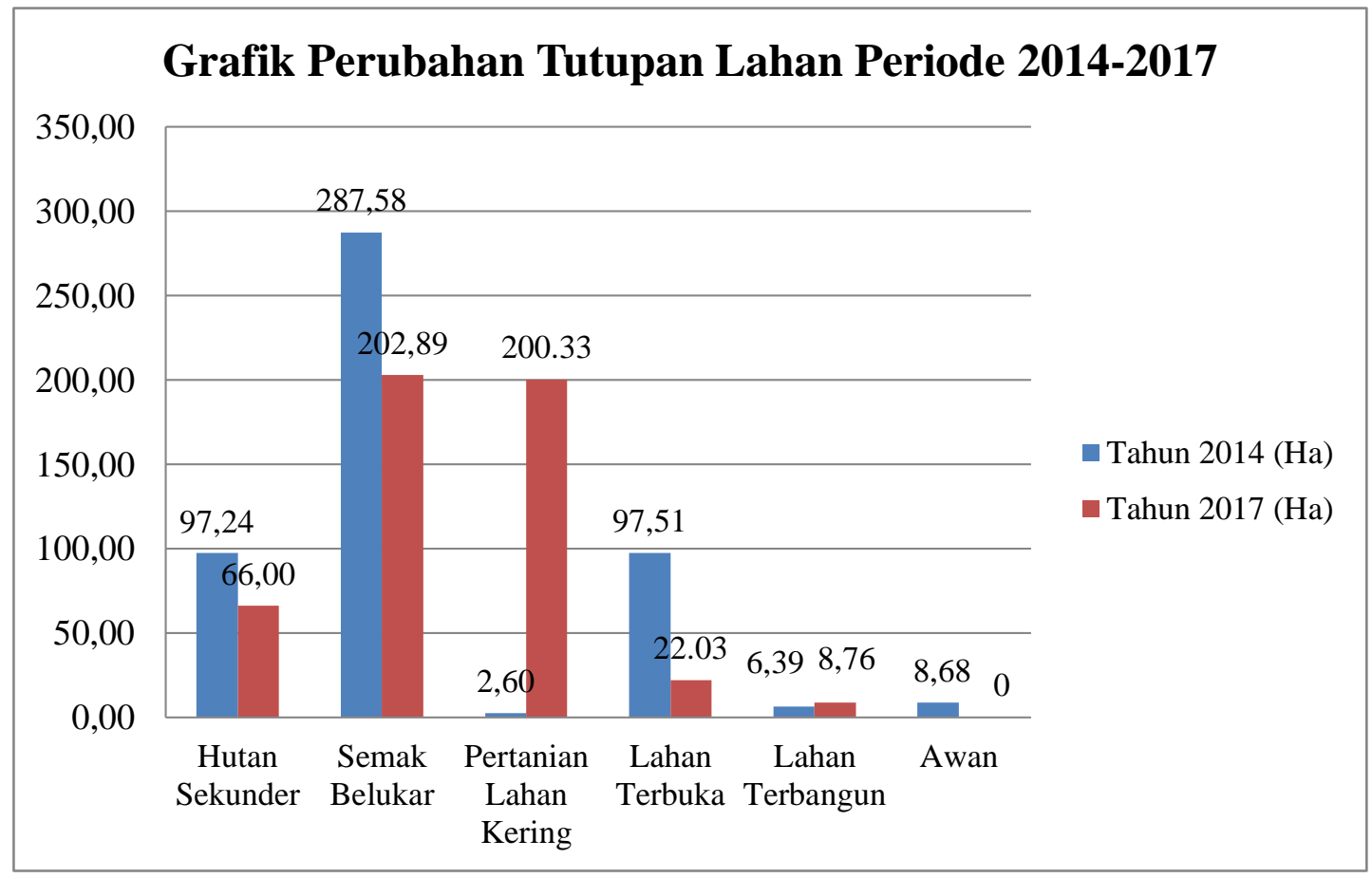

Gambar 1. Perubahan tutupan lahan periode $2014-2017$

\section{Tutupan Lahan Hasil Interpretasi Citra Tahun 2017 dan Tutupan Lahan Setelah Cheking Lapangan (Uji Ketelitian)}

Kegitan interpretasi citra perlu dilakukan survei/cek ulang lapangan sebagai uji ketelitian dengan membuat petak uji. Bila terdapat ketidaksesuaian antara peta dan hasil interpretasi citra satelit dengan hasil data lapangan, maka perlu ada koreksi dengan berpatokan pada pengecekan hasil lapangan (Uji Ketelitian). Uji ketelitian merupakan langkah yang diambil dalam menentukan tingkat kesesuaian citra hasil klasifikasi dengan kondisi aktual di lapangan. Pemeriksaan lapangan ini dilakukan untuk mencocokan hasil interpretasi citra yang telah dilakukan dengan kondisi sebenarnya dilapangan, pada saat pemeriksaan lapangan ini setiap kelas yang didapatkan melalui proses klasifikasi dari interpretasi citra disesuaikan langsung dengan objek yang ada dilapangan, objek dilapangan diambil fotonya sebagai penguat dari klasifikasi yang telah dibuat. 
Data ground check lapangan merupakan data primer fisik lapangan dengan cara pengambilan titik-titik GCP (Ground Control Point) langsung dilapangan. Pengambilan titik-titik ini GCP dilakukan dengan memakai GPS (Global Positioning System), yang berguna sebagai titik koreksi citra satelit dan dari hasil analisis interpretasi citra satelit dan peta topografi yang dibuat Pengambilan titik GCP untuk koreksi diambil yang telah ditentukan yang mewakili setiap kelas tutupan lahan, sedangkan untuk koreksi citra menggunakan titik tanda-tanda permanen (alam dan buatan) dan terlihat dari citra.

Titik GCP berguna sebagai patokan koreksi untuk hasil interpretasi penutupan lahan dari citra satelit, dalam koreksi ini berpatokan pada citra satelit tahun 2017. Bila terdapat ketidaksesuaian antara peta dan hasil interpretasi citra satelit dengan hasil data lapangan, maka perlu ada koreksi dengan berpatokan pada pengecekan hasil lapangan (titik-titik GCP). Jika terdapat ketidaksesuaian antara hasil interpretasi citra satelit tentang tutupan lahan dengan kedaan sebenarnya dilapangan maka perlu dilakukan koreksi dengan mendigitasi ulang kelas penutupan lahan.

Jika terdapat ketidaksesuaian antara hasil interpretasi citra satelit tentang tutupan lahan dengan kedaan sebenarnya dilapangan maka perlu dilakukan koreksi dengan mendigitasi ulang kelas penutupan lahan. Setelah melakukan interpretasi citra tahun 2017 terjadi perubahan tutupan lahan setelah melakukan cheking lapangan, namun perbandingan luas tutupan lahan dan cheking lapangan tidak begitu signitifikan (tetap), dimana dari enam tutupan lahan seperti 1 . Hutan sekunder, (2) semak belukar (3) pertanian lahan kering (4) lahan terbuka (5) lahan terbangun. Perubahan tersebut hanya terjadi pada tutupan lahan terbuka dan peningkatan tutupan lahan pertanian lahan kering, perubahan ini tidak terjadi pada tutupan lahan lainnya. Perubahan yang sangat cepat ini dikarenakan aktivitas pertanian yang terus berlangsung oleh masyarakat sekitar kawasan demi menunjang kesejahteraan masyarakat itu sendiri.

Tabel 4. Data Uji Ketelitian (Ground Check Lapangan)

\begin{tabular}{lllrr}
\hline \multirow{2}{*}{$\begin{array}{c}\text { No } \\
\text { Petak }\end{array}$} & \multicolumn{2}{c}{ Tipe Penutupan Lahan } & \multicolumn{2}{c}{ Koordinat Lapangan } \\
\cline { 2 - 5 } & Citra Tahun 2017 & Kondisi Lapangan & BT & LS \\
\hline 1 & Hutan Sekunder & Hutan Sekunder & $107^{\circ} 43^{\prime} 39,1^{\prime \prime}$ & $07^{\circ} 13^{\prime} 52,3^{\prime \prime}$ \\
2 & Semak Belukar & $\begin{array}{l}\text { Semak Belukar } \\
\text { Pertanian }\end{array}$ & $107^{\circ} 43^{\prime} 40,7^{\prime \prime}$ & $07^{\circ} 12^{\prime} 44,1^{\prime \prime}$ \\
3 & Lahan & & \\
& Lahan Terbuka & Kering & $107^{\circ} 43^{\prime} 55,0^{\prime \prime}$ & $07^{\circ} 13^{\prime} 08,0^{\prime \prime}$ \\
4 & Pertanian Lahan & Pertanian Lahan & & \\
5 & Kering & Kering & $107^{\circ} 43^{\prime} 46,4^{\prime \prime}$ & $07^{\circ} 12^{\prime} 58,6^{\prime \prime}$ \\
5 & Lahan Terbangun & Lahan Terbangun & $107^{\circ} 43^{\prime} 39,0^{\prime \prime}$ & $07^{\circ} 13^{\prime} 05,0^{\prime \prime}$ \\
\hline
\end{tabular}


Tabel 5. Perubahan Tutupan Lahan Hasil Interpretasi Tahun 2017 dan Hasil Uji Ketelitian (Ground Check Lapangan)

\begin{tabular}{|c|c|c|c|}
\hline \multirow{2}{*}{ No } & \multirow{2}{*}{ Tutupan Lahan } & Interpretasi Citra 2017 & Cheking Lapangan \\
\hline & & Luas (Ha) & Luas (Ha) \\
\hline 1 & Hutan Sekunder & 66.00 & 66.00 \\
\hline 2 & Semak Belukar & 202.89 & 202.89 \\
\hline 3 & Pertanian Lahan Kering & 200.33 & 201.85 \\
\hline 4 & Lahan Terbuka & 22.03 & 20.51 \\
\hline 5 & Lahan Terbangun & 8.76 & 8.76 \\
\hline
\end{tabular}

Tabel.6. Perubahan Luas Hasil Interpretasi Citra tahun 2014 dan Tahun 2017 Hasil Uji Ketelitian (Ground Check Lapangan)

\begin{tabular}{llcc}
\hline No & Tutupan Lahan & Tutupan Lahan 2014 & $\begin{array}{c}\text { Tutupan Lahan } \\
\text { Setelah Cheking } \\
\text { Lapangan }\end{array}$ \\
\cline { 3 - 4 } & & Luas (Ha) & Luas (Ha) \\
1 & Hutan Sekunder & 97,24 & 66.00 \\
2 & Semak Belukar & 287,58 & 202.89 \\
3 & Pertanian Lahan Kering & 2,60 & 201.85 \\
4 & Lahan Terbuka & 97,51 & 20.51 \\
5 & Lahan Terbangun & 6,39 & 8.76 \\
6 & Awan & 8,68 & - \\
\hline
\end{tabular}

Hasil uji ketelitian lapangan terhadap data hasil interpretasi citra tahun 2017 pada Tabel 5, yaitu adanya perubahan penggunaan lahan pada lahan terbuka menjadi pertanian lahan kering, tutupan lahan terbuka dari data hasil interpretasi citra tahun 2017 seluas 22.03 Ha akan tetapi terjadi perubahan luasan setelah cheking lapangan menjadi $20.51 \mathrm{Ha}$, pengurangan luasan lahan terbuka ini dikarenakan adanya konversi lahan menjadi pertanian lahan kering sehingga terjadi peningkatan pada pertanian lahan kering, dari hasil interpretasi citra tahun 2017 seluas $200.33 \mathrm{Ha}$ (40.18\%) menjadi $201.85 \mathrm{Ha}$ (40.07\%) setelah cek/survei lapangan. Hal ini aktivitas konversi lahan menjadi pertanian lahan kering terus berlangsung dalam kurun waktu yang singkat oleh masyarakat sekitar dalam perluasan lahan yang digarapnya, perubahan penggunaan lahan dalam waktu yang singkat ini akan berpengaruh terhadap luasan tutupan lahan yang lainnya.

Kawasan lahan terbuka telah terjadi penurunan luasan tutupan lahan, pada hasil interpretasi citra tahun 2017 seluas $22.03 \mathrm{Ha}(4.41 \%)$ menjadi $20.51 \mathrm{Ha}$ $(4.10 \%)$. setelah cek/survei lapangan. Laju pengurangan kawasan lahan terbuka ini dikarenakan terjadinya perubahan tutupan lahan menjadi pertanian lahan kering. Perbandingan perubahan tutupan lahan selama kurun waktu 3 tahun yaitu 
hasil penafsiran citra tahun 2014 dengan hasil penafsiran citar tahun 2017 (setelah uji lapangan) seperti pada tabel 6.

\section{Tutupan Lahan Hasil Interpretasi Citra Tahun 2014 dan Tutupan Lahan Setelah Cheking Lapangan}

Hasil interpretasi citra tahun 2014 dan tutupan lahan setelah cheking lapangan dikawasan hutan lindung RPH simpang BKPH bayongbong mengalami perubahan tutupan lahan pada setiap tipe tutupan lahannya. Dalam kurung waktu 3 tahun dari tahun 2014 dan hasil cheking lapangan telah terjadi perubahan luas areal tutupan lahan yang terjadi di dalamnya. Perubahan tutupan lahan tahun 2014 dan hasil cheking lapangan ini adalah kondisi sebenarnya dilapangan, dimana telah terjadi perubahan luasan pada tutupan lahan pertanian lahan kering dan tutupan lahan terbuka, perubahan luasan dari tahun 2014 dan tahun 2017 (setelah cheking lapangan) ini sebagai perbandingan.

\section{Pertanian Lahan Kering}

Kawasan pertanian lahan kering terjadi perubahan fluktuasi yang sangat besar dari tipe tutupan lahan lainnya dimana terjadi peningkatan luasan, pada tahun 2014 seluas $2.60 \mathrm{Ha}$ (0.52\% dari total luas lokasi penelitian) menjadi seluas $201.85 \mathrm{Ha}(40.37 \%$ ) pada tahun 2017 (setelah cheking lapangan). Laju penambahan luasan pertanian lahan kering dari tahun 2014 sampai tahun 2017 sebesar 199.25 Ha atau rata-rata sebesar $66.42 \mathrm{Ha} /$ tahun. Luasan pertanian lahan kering bertambah dikarenakan adanya kegiatan konversi lahan terbuka dan perladangan oleh masyarakat, setelah melakukan wawancara dengan beberapa masyarakat yang melakukan kegiatan pertanian lahan kering adalah berasal dari masyarakat desa sekitar lokasi kawasan hutan yang telah lama menggarap lahan dikawasan tersebut, masyarakat menggarap untuk menanam sayuran seperti halnya kentang dan kol.

Dimana masyarakat desa pada umumnya hanya mengandalkan sumber mata pencariannya dari sektor pertanian. Keterbatasan lahan yang dimiliki oleh setiap keluarga serta peningkatan kebutuhan menyebabkan sebagian masyarakat yang kurang mampu melakukan penggarapan lahan dan konversi lahan untuk perluasan areal pertaniannya. Mereka sadar akan dampak yang dihasilkan terhadap lingkungan ketika masyarakat menggarap dikawasan tersebut, baik itu akan terjadi erosi, banjir dan dampak lainnya dikarenakan petugas pemangku kawasan intens melakukan penyuluahan kepada masyarakat akan tetapi mereka tetap melakuakan perladangan diskeitar kawasan untuk menunjang kebutuahan meraka. 


\section{Lahan Terbuka}

Kawasan lahan terbuka telah terjadi penurunan luasan dari tahun 2014 seluas $97.51 \mathrm{Ha}(19,50 \%$ dari total luas lokasi penelitian) menjadi $20.51 \mathrm{Ha}$ (40.10\%) pada tahun 2017 setelah cheking lapangan. Laju pengurangan kawasan lahan terbuka dari tahun 2014 sampai tahun 2017 sebesar 77 Ha atau sebesar 25.7 $\mathrm{Ha} /$ tahun. Pengurangan luasan ini karenakan terjadinya konversi menjadi bangunan sebesar 2.37 Ha dan pertanian lahan kering seluas 74.63 Ha. Kawasan tersebut akan dijadikan kawasan pertanian lahan kering oleh masyarakat yang menggarap, diamana setelah dilakuakan cheking lapanagn terjadi perubahan tutupan lahan menjadi pertanian lahan kering seluas 1.52 Ha. Jika kawasan lahan terbuka dibiarkan dan bertambahannya semakin besar dikhawatirkan daerah resapan air untuk wilayah hulu DAS Cimanuk akan semakin sedikit dan berakibat buruk bagi sistem hirdrologi.

\section{Deforestasi Pada Lokasi Penelitian}

Deforestasi merupakan sebuah istilah yang menggambarkan hilangnya hutan secara permanen maupun sementara menjadi lahan untuk tujuan lain dikarenakan ada aktivitas manusia dikawasan hutan. Berdasarkan hasil intrpretasi citra Landsat OLI tahun 2014 dan 2017 diketahui bahwa dalam kurun waktu tersebut telah terjadi deforestasi atau kehilanagan tutupan hutan diareal kawasan hutan lindung RPH Simpang BKPH Bayongbong, akibat dari kegiatan konversi tutupan hutan sekunder menjadi tutupan lahan lain untuk tujuan tertentu. Temuan ini sangat mengherankan dimana tutupan hutan yang paling luas berada dikawasan kabupaten garut yang menjadi target pemerintah dalam target green province pada masa yang akan datang oleh gubernur Jawa Barat. Pada gambar.16. Disajikan grafik deforestasi pada tutupan hutan sekunder dari tahun 2014 sampai dengan tahun 2017 dibawah ini :

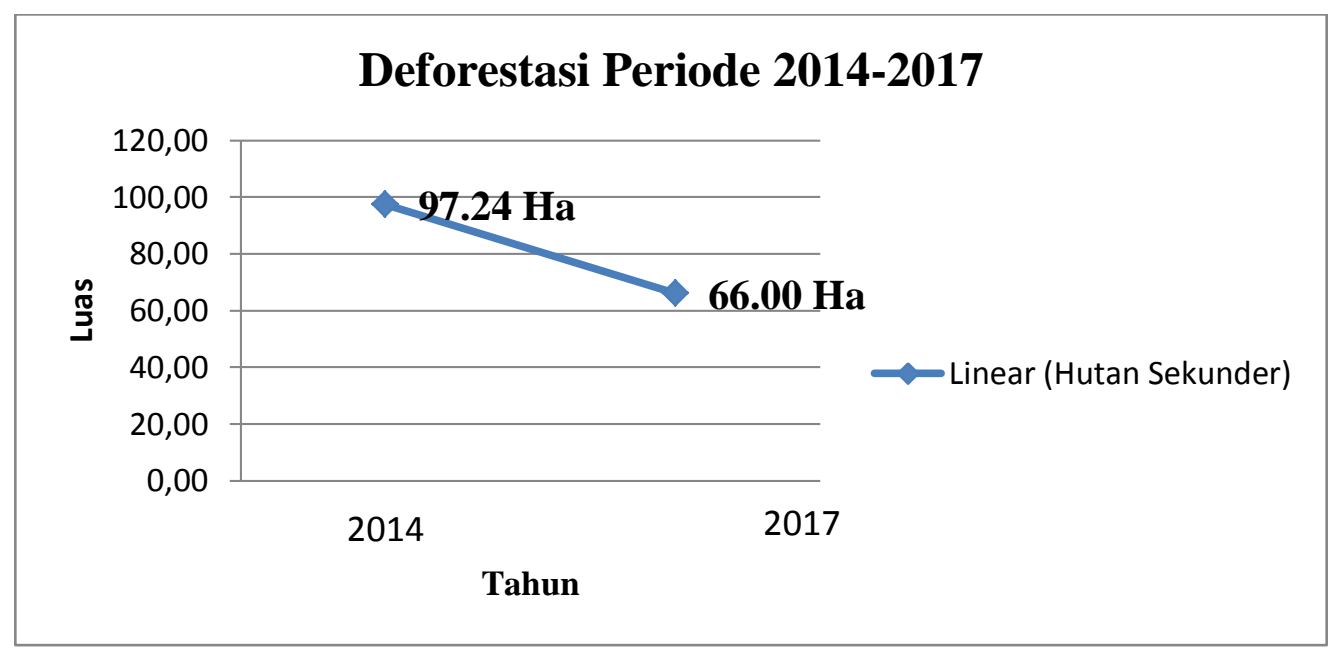

Gambar 5. Grafik Deforestasi Tutupan Hutan Sekunder 
Berdasarkan grafik diatas bahwa selama kurun waktu tahun 2014-2017 telah terjadi perubahan tutupan lahan hutan sekunder menjadi tutupan lain (deforestasi) diareal penelitian, luas deforestasi dihutan lindung RPH Simpang BKPH Bayongbong dalam kurun waktu tiga tahun seluas $31.24 \mathrm{Ha}$ atau $32.13 \%$ dari luas tutupan hutan sekunder sebelumnya, dimana hilangnya hutan sekunder dikawasan penelitian ini diakibatkan adanya konversi lahan menjadi semak belukar seluas 27.13 Ha dan menjadi pertanian lahan kering seluas 4.11 Ha.

Perubahan tutupan lahan yang terjadi pada kawasan hutan lindung RPH Simpang BKPH Bayongbong Kabupaten Garut dari tahun 2014 sampai dengan tahun 2017, menurut Naiman (1992) menyimpulkan bahwa pengelolaan sumberdaya hutan sangat kompleks dan penuh ketidakpastian karena perubahan dalam sistem demokrasi, kekuatan sosial politik dan harapan masyarakat. Selanjutnya, keputusan dan tekanan terhadap penggunaan lahan makin meningkat akibat faktor-faktor ekonomi dan sosial secara luas. Pemanfaatan kawasan budidaya untuk memenuhi kebutuhan hidup manusia harus diusahakan tidak mengganggu dan merusak ekosistem kawasan lindung. Perubahan penggunaan yang tidak terkendali dan tanpa tindakan konservasi tanah dan air akan menyebabkan terjadinya erosi. Erosi yang terjadi dapat menyebabkan degradasi lahan, yang akhirnya menyebabkan menurunya produktivitas lahan (Adnyana, 2011).

Bila kondisi tersebut dibiarkan dan berkembang terus tanpa adanya upaya rehabilitasi lahan dan konservasi tanah maka dikhawatirkan akan sangat potensial dalam meningkatkan percepatan laju erosi. Kegiatan manusia yang paling berpengaruh terhadap erosi adalah cara-cara manusia dalam memanfaatkan sumberdaya lahan. Setiap tipe penggunaan lahan akan mempunyai pengaruh yang berbeda terhadap besarnya erosi yang terjadi, tipe pemanfaatan lahan di hutan lindung RPH Simpang BKPH Bayongbong didominasi oleh semak belukar dan pertanian lahan kering. Kondisi penggunaan lahan yang masih seperti ini memberikan indikasi bahwa kondisi kawasan resapan air hulu Daerah Aliran Sungai Cimanuk secara umum telah mengalami penuruanan fungsi yang besar yang mengakibatkan menimbulkan masalah lingkungan yang kompleks, salah satunya masalah banjir dan erosi dikarenakan berkurangnya daerah resapan air.

\section{Pencegahan Perubahan Lahan}

Berdasarkan hasil wawancara baik pemangku kawasan dan masyarakat yang menggarap dikawasan teresebut, beberapa hal dalam rangka pencegahan adanya perubahan telah dilakukan oleh pihak Perum perhutani namun beberapa kegiatan belum efektif karena masih munculnya pengalihfungsian lahan di dalam 
kawasan. Kegiatan yang dilakukan oleh petugas Perum Perhutani sebagai upaya pencegahan terjadinya perubahan lahan diantaranya dengan sosialisasi dan penyuluhan terhadap masyarakat sekitar hutan terkait dengan penggunaan lahan serta dampak buruk terhadap lingkungan sekitar apabila menggarap lahan pertanaian dikawasan.

\section{KESIMPULAN}

Kesimpulan yang dapat diambil pada penelitian ini adalah :

1. Dari hasil interpretasi citra tutupan lahan kawasan Hutan Lindung RPH Simpang BKPH Bayongbong dapat diklasifikasikan kedalam enem tipe tutupan lahan, yaitu : 1. Hutan sekunder, (2) semak belukar (3) pertanian lahan kering (4) lahan terbuka (5) lahan terbangun (6) awan. Pada tahun 2014 tutupan lahan terluas terdapat pada tipe semak belukar dengan luas $287.58 \mathrm{Ha}$ atau sekitar $57.52 \%$ dari luas kawasan dan pada tahun 2017 tutupan lahan terluas adalah tipe semak belukar dengan seluas 202.89 Ha atau sekitar 40.58 $\%$ dari luas kawasan yang diteliti.

2. Dari hasil interpretasi citra perubahan tutupan lahan yang terjadi selama periode tahun 2014 sampai dengan tahun 2017 yang mengalami penurunan luas wilayah adalah tutupan lahan tipe hutan sekunder seluas $31.24 \mathrm{Ha}$, semak belukar seluas $84.69 \mathrm{Ha}$ dan lahan terbuka seluas $75.48 \mathrm{Ha}$.

3. Dari hasil interpretasi citra perubahan tutupan lahan yang terjadi selama periode tahun 2014 sampai dengan tahun 2017 yang mengalami peningkatan luas wilayah adalah tutupan lahan pertanian lahan kering seluas 196,73 Ha dan tutupan lahan terbangun seluas 2,37 Ha.

4. Setelah melakukan pengecekan lapangan (Uji ketelitian) terjadi perubahan pada tutupan lahan terbuka menjadi pertanian lahan kering pada kawasan petak uji, sehingga tutupan lahan terbuka menjadi berkurang seluas $1.52 \mathrm{Ha}$ dan terjadi peningkatan luasan pada kawasan pertanian lahan kering seluas $1.52 \mathrm{Ha}$.

5. Laju deforestasi selama periode tahun 2014 sampai dengan tahun 2017 seluas -31.24 Ha. diakibatkan adanya konversi lahan menjadi semak belukar seluas 27.13 Ha dan menjadi pertanian lahan kering seluas 4.11 Ha. 


\section{DAFTAR PUSTAKA}

Adnyana, I.W.S. 2011. Perubahan Penggunaan Lahan di Kawasan Bedugul dalam: Adnyana. I.W.S Arthana. I.W. As-Syukur. A.R. editor. Perubahan Penggunaan Lahan dan Daya Dukung Lingkungan. Udayana University Press. 1-10. Denpansar.

Arsyad, S. 2006. Konservasi Tanah dan Air. Cetakan Kedua. Institut Pertanian Bogor Press. Dermaga. Bogor.

Badan Pusat Statistik Kabupaten Garut. 2016 Garut dalam angka. Garut.

Badan Pusat Statistik Kabupaten Garut. 2016 Kecamatan Cisusrupan dalam angka. Garut.

Badan Pusat Statistik Kabupaten Garut. 2016 Kecamatan Pasirwangi dalam angka. Garut.

Badan Pusat Statistik Kabupaten Garut. 2016 Kecamatan Sukaresmi dakam angka. Garut.

Baja S. 2012. Perencanaan Tata Guna Lahan dalam Pengembangan Wilayah. Yogyakarta (ID). Penerbit ANDI.

Dinas Kehutanan Kabupaten Garut 2015.

Feri, T. 2007. Analisis Perubahan Lahan dan Keterkaitannya Dengan Fluktuasi Debit Sungai di Sub-Das Antokan Propinsi Sumatera Barat. Thesis. SPSIPB. Bogor.

FWI (Forest Watch Indonesia), 2014. Potret Keadaan Hutan Indonesia Periode $2009-2013$.

Jaya, I.N.S. 2010. Analisis Citra Digital : Perspektif Penginderaan Jauh untuk

Pengelolaan Sumber Daya Alam. IPB Press. Bogor. 195 hal

Jia K, Xiangqin W, Xingfa G, Yunjun Y, Xianhong X, Bin L. 2014. Land cover

classification using Landsat 8 Operational Land Imager data in Beijing, China.

Geocarto International. 29: 941-951.

Kementerian Lingkungan Hidup dan Kehutanan Direktorat Jendral Planologi Kehutanan. 2015.

Kementerian Lingkungan Hidup dan Kehutanan. 2011. Pembangunan Kesatuan

Pengelolaan Hutan (KPH) Konsep, Peraturan Perundangan dan Implementasi.

Direktorat Wilayah Pengelolaan dan Penyiapan Areal Pemanfaatan Kawasan Hutan. Jakarta.

LAPAN, 1999. Proyek Rancan Bangun dan Rekayasa Teknologi Penginderaan Juah : Kebijaksanaan Kelautan/Kedirgantaraan Kajian Satelit Masa Depan. Landsat 7. Bidang Pengolahan Data. Pust Teknologi Penginderaan Jauh. Jakarta. 
Lillesand, TM. and Kiefer FW.1999. Penginderaan Jauh dan Interpretasi Citra. Ahli bahasa. R. Dubhari. Gadjah Mada University Press. Yogyakarta.

Lo, C.P 1996. Penginderaan Jauh Terapan. Terjemahan Bambang Purbowaseso Jakarta : UI-PRESS.

Naiman, R.J., (Ed). (1992). Watershed Management Balancing Sustainability and Environmental Change. Springer. USA.

Nugraha, S. 2011. Kesesuaian Fungsi Kawasan Dengan Pemanfaatan Lahan didaerah Aliran Sungai Samin.

Prahasta E. 2008. Sistem Informasi Geografis : Konsep-konsep Dasar (Perspektif Geodesi \& Geomatika).Bandung (ID): Penerbit Informatika.

Peraturan Pemerintah Republik Indonesia Nomor 10 Tahun 2010. Tentang Tata Cara Perubahan Peruntukan Dan Fungsi Kawasan Hutan.

Purwadhi, 2008. Pengantar Interpretasi Citra Penginderaan Jauh. Lembaga Penerbangan Antariksa Nasional : Jakarta.

Rachman Effendi, Indah Bangsawan, and Muahamad Zahrul M. 2007. Kajian pola-pola pembeerdayaan masyarakat sekitar hutan produksi dalam mencegah illegal logging. Jurnal Penelitian Sosial Ekonomi Kehutanan Vol. 4 Desember 2007.

SK Menhut No. 195/Kpts-II/2003 tentang Penunjukan Kawasan Hutan di Wilayah Provinsi Jawa Barat,

Silviani, 2008. Kajian dampak perubahan fungsi kawasan hutan terhadap masyarakat sekitar. Jurnal Penelitian Sosial dan Ekonomi Kehutanan Vol.5 No. 3 Sepetember 2008.

Sunderlin WD dan Ida Aju PR. 2012. Laju dan Penyebab Deforestasi diIndonesia; Penelaahan Kerancuan dan Penyelesaiannya. Bogor (ID): CIFOR.

Wahyunto, 2007. Peranan Citra Satelit Dalam Penentuan Potensi Lahan. Http://www.litbang.deptan.go.id/warta-ip/pdf-file/wahyunto-13.html. Desember 2016] 